\title{
Crystal structure of sparteinium tetrachlorocuprate monohydrate-packing polymorph
}

\author{
Piotr Kuś ${ }^{1}$ · Joachim Kusz ${ }^{2}$. Maria Książek ${ }^{2}$. Hubert Hellwig ${ }^{1}$ Sławomir Maślanka ${ }^{1}$
}

Received: 7 January 2019 / Accepted: 11 April 2019 / Published online: 17 June 2019

(c) The Author(s) 2019

\begin{abstract}
A new polymorph of sparteinium tetrachlorocuprate monohydrate $\left[\left(\mathrm{C}_{15} \mathrm{H}_{28} \mathrm{~N}_{2}\right) \mathrm{CuCl}_{4} \cdot \mathrm{H}_{2} \mathrm{O}\right]$ is reported. The structure of the analyzed crystal was solved in the orthorhombic $P 2{ }_{1}{ }_{2} 2_{1}$ space group with the following unit cell parameters at $295 \mathrm{~K}$ : $a=9.7722(2) \AA ; b=13.4582(3) \AA ; c=15.1582(3) \AA$. The various types of hydrogen bonding interactions existing in the crystal structure of this salt were compared with the data of the previously reported polymorph. XRPD measurement proved that our salt consists of a pure phase of the new polymorph. Cooling down the salt to ca. $230 \mathrm{~K}$ caused its color to change from orange-brown to yellow. DSC experiments revealed that during the cooling an endothermic process takes place corresponding to the mentioned color change of the salt.
\end{abstract}

\section{Graphical abstract}

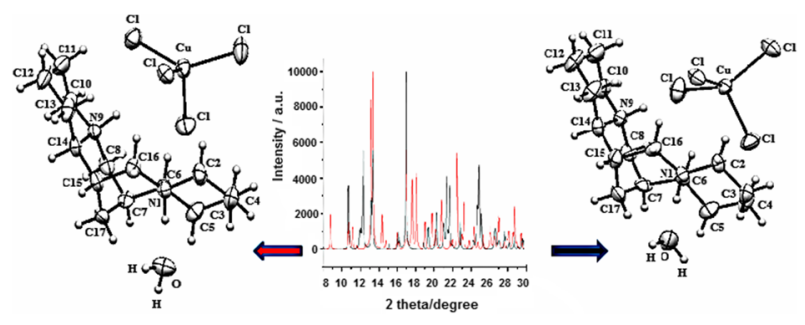

Keywords IR spectra $\cdot$ DSC $\cdot$ Hydrogen bonding $\cdot$ Polymorphism $\cdot$ Raman spectra

\section{Introduction}

(-)-Sparteine, an alkaloid naturally occurring in plants from Lupinus, Laburnum, Spartium, Genista, Saratamnus and other genera of Fabaceae family is a sodium channel inhibitor used as an antiarrhythmic drug. Sparteine occurs

Electronic supplementary material The online version of this article (https://doi.org/10.1007/s00706-019-02426-2) contains supplementary material, which is available to authorized users.

Piotr Kuś

pkus@ich.us.edu.pl

1 Department of Chemistry, University of Silesia, 9, Szkolna Street, 40-006 Katowice, Poland

2 Institute of Physics, University of Silesia, 1, 75 Pułku Piechoty, 41-503 Chorzów, Poland in nature as levo- and dextrorotatory. The latter enantiomer, called pachycarpine, is toxic.

The presence of two amine atoms in the structure of sparteine led to its use as a bidentate ligand in various complexes (e.g., involving copper [1-13]). Following quaternization of both nitrogen atoms in the molecule sparteine was used as a dication in metalloorganic copper salts $[14,15]$.

While searching for novel complexes with thermochromic properties we synthesized a previously described salt of this alkaloid with copper ions (Fig. 1). The synthesis was performed according to the reported methods so we expected a salt identical with that obtained before $[14,15]$. 


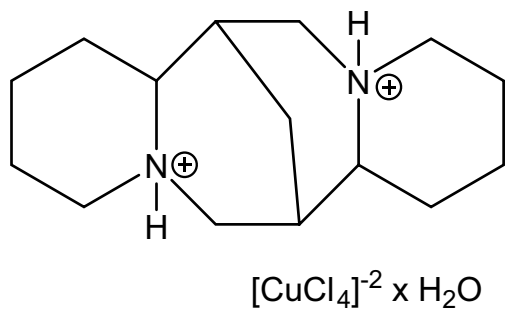

Fig. 1 Structure of sparteinium tetrachlorocuprate monohydrate salt

Table 1 Selected geometrical data for salt $\mathbf{1}$ obtained at room temperature

\begin{tabular}{llll}
\hline & $\mathbf{1}$ & & $\mathbf{1}$ \\
\hline $\mathrm{Cu}-\mathrm{Cl} 1 / \AA$ & 2.371 & $\mathrm{Cl} 1-\mathrm{Cu}-\mathrm{Cl} 2 /^{\circ}$ & 102.29 \\
$\mathrm{Cu}-\mathrm{Cl} 2 / \AA$ & 2.215 & $\mathrm{Cl} 1-\mathrm{Cu}-\mathrm{Cl} 3 /^{\circ}$ & 100.51 \\
$\mathrm{Cu}-\mathrm{Cl} 3 / \AA$ & 2.211 & $\mathrm{Cl} 1-\mathrm{Cu}-\mathrm{Cl} 4 /^{\circ}$ & 117.64 \\
$\mathrm{Cu}-\mathrm{Cl} 4 / \AA$ & 2.214 & $\mathrm{Cl} 2-\mathrm{Cu}-\mathrm{Cl} 3 /^{\circ}$ & 133.87 \\
& & $\mathrm{Cl} 2-\mathrm{Cu}-\mathrm{Cl} 4 /^{\circ}$ & 100.28 \\
& & $\mathrm{Cl} 3-\mathrm{Cu}-\mathrm{Cl} 4 /^{\circ}$ & 103.73 \\
$\mathrm{~N} 1-\mathrm{N} 9 / \AA$ & 3.667 & $\mathrm{Cu}-\mathrm{O} / \AA$ & 7.939 \\
$\mathrm{Cu}-\mathrm{N} 1 / \AA$ & 5.350 & $\mathrm{~N} 1-\mathrm{O} / \AA$ & 2.733 \\
$\mathrm{Cu}-\mathrm{N} 9 / \AA$ & 4.471 & & \\
\hline
\end{tabular}

\section{Results and discussion}

Selected interatomic bond lengths and angles for sparteinium tetrachlorocuprate monohydrate (1) salt obtained at room temperatures are shown in Table 1. Summary of crystallographic data for salt $\mathbf{1}$ are shown in Table 2.

\section{Crystallographic properties of the obtained salt}

The salt obtained by us, identical with those reported by Lee et al. [14] and Jasiewicz et al. [15], markedly differed from them in parameters of the unit cell and its volume, with isomorphic space group $\left(P 2_{l} 2_{l}{ }_{l}\right)$ and same number of molecules in unit cell $(Z=4)$. The salts described in this paper and in [14] were obtained using similar methods and same solvent (ethanol) and copper salt $\left(\mathrm{CuCl}_{2} \times 2 \mathrm{H}_{2} \mathrm{O}\right)$, however, sparteine used by us was in the form of sulfate whereas that used in [14] was pure alkaloid. The salt described in [15] has been obtained as a byproduct during the synthesis of $\alpha$-isosparteine tetrachlorocuprate. Comparison of the crystallographic data presented in $[14,15]$ shows that in both papers this same polymorph is described. Crystallographic studies were performed at similar room temperatures. This is significant, because this salt exhibits thermochromic properties at low temperatures. Crystallographic examination of our salt was also carried out at $100 \mathrm{~K}$, because this salt at about $230 \mathrm{~K}$ starts slowly changing the color from orange to yellow which should reflect changes in crystallographic structure.

XRPD measurements of the batch procured in our experiments show that the new polymorph formed as a pure phase (Fig. 2). Figure 3 shows the comparison of XRPD patterns for salt 1 (red line) and salt reported in [15] (black line) calculated from single-crystal data of both polymorphs.

The molecular units of salt $\mathbf{1}$ at both measured temperatures are built through the formation of several weak hydrogen bonds between the sparteinium nitrogen atoms, chlorine atoms of the anions, and water molecules. The $\mathrm{N} \cdots \mathrm{Cl}$ distances in reported polymorph are only slightly shorter $(3.183 \AA)$ than those reported in [14] (3.280 $\mathrm{A})$ and [15] $(3.286 \AA)$. These bonds are shorter in $100 \mathrm{~K}(3.143 \AA)$. The $\mathrm{H}$... Cl distances range from 2.220 to $2.367 \AA$ (shorter than sum of Van der Waals radii $=2.95 \AA$ ) with the $\mathrm{N}-\mathrm{H} \cdots \mathrm{Cl}$ angles are between $152.94^{\circ}$ and $166.76^{\circ}$ (Figs. 4, 5).

The shortest distance between chlorine atoms of two different $\mathrm{CuCl}_{4}^{-2}$ ions in salt $\mathbf{1}$ is $3.896 \AA$ (at $295 \mathrm{~K}$ ) and 3.820 $\AA$ (at $100 \mathrm{~K}$ ), not particularly greater than the sum of van der Waals radii for two chlorine atoms (3.60 $\AA$ ) and considerably shorter than the values reported in [14] (4.523 $\AA$ ) and [15] $(4.525 \AA)$. The near distance between copper atoms in salt $1(7.897 \AA)$ is shorter compared to those in the polymorph described earlier where these distances are $8.221 \AA$ [14] and $8.228 \AA$ [15], respectively. Distances between copper atoms and nearest chlorine atoms not linked to the former are 5.757 $\AA$ for salt 1 (5.950 $\AA$ and $5.951 \AA$ for previously described polymorph in $[14,15]$, respectively). This distance is too long to allow formation of $\mathrm{Cu}-\mathrm{Cl}-\mathrm{Cu}$ bridge.

The most obvious difference between the two polymorphs is the orientation of the $\mathrm{CuCl}_{4}^{-2}$ anions relative to sparteinium molecules (and also $\mathrm{H}_{2} \mathrm{O}$ molecules). The average $\mathrm{O}-\mathrm{H} \cdots \mathrm{Cl}$ distances lie within $2.320-2.530 \AA$ range for one chlorine atom and within $2.279-2.903 \AA$ range for the other chlorine atom. These values pertain to the same anion in case of the reported salt, and to two different anions for salts reported in $[14,15]$, which is shown in Fig. 1S (supplementary materials).

While cooling down a sample of the salt in liquid nitrogen, we noticed that it changes the color from orange to yellow and returns quickly to the former color following slight warming (Photo 1 -supplementary materials). This process was repeated several times without any visible change in the external appearance of the sample (crystals did not change their shape or color). We decided to perform crystallographic measurements of a monocrystal at $100 \mathrm{~K}$. Much to our surprise, while changing color, the crystal did not alter drastically the parameters of the unit cell. When analyzing particular fragments of the salt and comparing results to the previously obtained structure at $295 \mathrm{~K}$ we concluded that the differences in values of relevant distances in 
Table 2 Crystal data, data collection, and structure refinement for salt $\mathbf{1}$ at $295 \mathrm{~K}$ and $100 \mathrm{~K}$, respectively

\begin{tabular}{|c|c|c|}
\hline Chemical formula & $\mathrm{C}_{15} \mathrm{H}_{30} \mathrm{~N}_{2} \mathrm{O}_{1} \mathrm{Cu}_{1} \mathrm{Cl}_{4}$ & $\mathrm{C}_{15} \mathrm{H}_{30} \mathrm{~N}_{2} \mathrm{O}_{1} \mathrm{Cu}_{1} \mathrm{Cl}_{4}$ \\
\hline$M_{r}$ & 459.75 & 459.75 \\
\hline$T / \mathrm{K}$ & 295 & 100 \\
\hline Wavelength/A & 0.71073 & 0.71073 \\
\hline Crystal system & Orthorhombic & Orthorhombic \\
\hline Space group & $P 2_{1} 2_{1} 2_{1}$ & $P 2_{1} 2_{1} 2_{1}$ \\
\hline \multicolumn{3}{|l|}{ Unit cell dimensions } \\
\hline$a / \AA$ & $9.7722(2)$ & $9.7152(1)$ \\
\hline$b / \AA$ & $13.4582(3)$ & $13.3623(2)$ \\
\hline$c / \AA$ & $15.1582(3)$ & $15.0337(2)$ \\
\hline$V / \AA^{3}$ & $1993.55(7)$ & $1951.64(4)$ \\
\hline$D_{\text {calc }} / \mathrm{Mg} \mathrm{m}^{-3}$ & 1.532 & 1.565 \\
\hline$Z$ & 4 & 4 \\
\hline Absorption coefficient $/ \mathrm{mm}^{-1}$ & 1.636 & 1.671 \\
\hline$F(000)$ & 956 & 956 \\
\hline Crystal size & $0.13 \times 0.04 \times 0.03$ & $0.13 \times 0.04 \times 0.03$ \\
\hline Theta range for data collection $/^{\circ}$ & $2.905-26.368$ & $2.925-26.357$ \\
\hline \multirow[t]{3}{*}{ Index ranges } & $-11 \leq h \leq 12$ & $-12 \leq h \leq 11$ \\
\hline & $-16 \leq k \leq 16$ & $-16 \leq k \leq 16$ \\
\hline & $-18 \leq l \leq 18$ & $-18 \leq l \leq 18$ \\
\hline Reflections collected & 16,079 & 15,759 \\
\hline Independent reflections & $4069\left[R_{(\mathrm{int})}=0.0299\right]$ & $3979\left[R_{\text {(int) }}=0.0180\right]$ \\
\hline Data/restraints/parameters & $4069 / 0 / 208$ & $3979 / 0 / 208$ \\
\hline Goodness-of-fit on $F^{2}$ & 1.056 & 1.061 \\
\hline \multirow[t]{2}{*}{ Final $R$ indices $[I>2 \sigma(I)]$} & $R 1=0.0265$ & $R 1=0.0152$ \\
\hline & $w R 2=0.0654$ & $w R 2=0.0403$ \\
\hline \multirow[t]{2}{*}{$R$ indices (all data) } & $R 1=0.0295$ & $R 1=0.0156$ \\
\hline & $w R 2=0.0680$ & $w R 2=0.0406$ \\
\hline Largest diff. peak and hole/e $\AA^{-3}$ & 0.446 and -0.414 & 0.254 and -0.326 \\
\hline
\end{tabular}

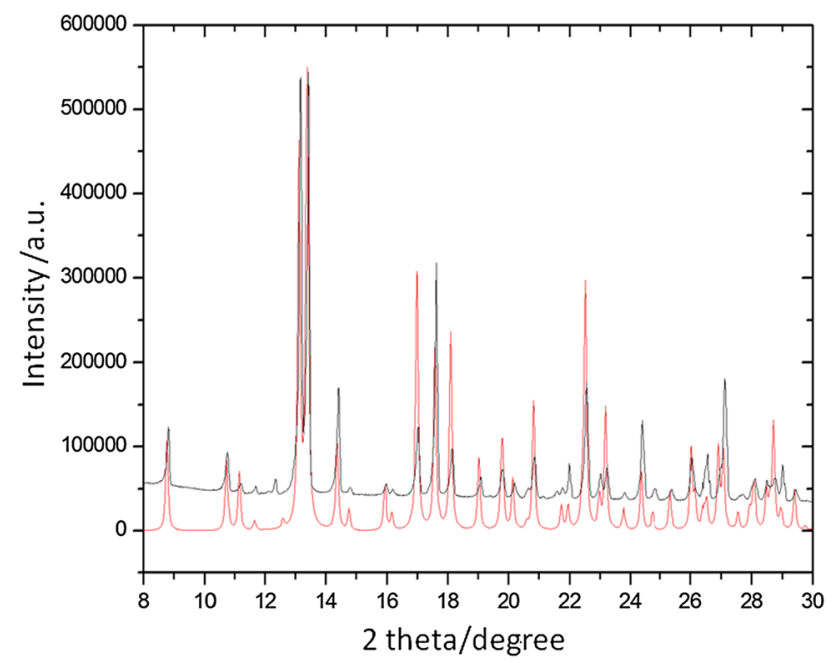

Fig. 2 XRPD patterns of the material obtained from our synthesis (black line) and XRPD patterns for salt 1 calculated from single-crystal data measured at $295 \mathrm{~K}$ (red line) (color figure online)

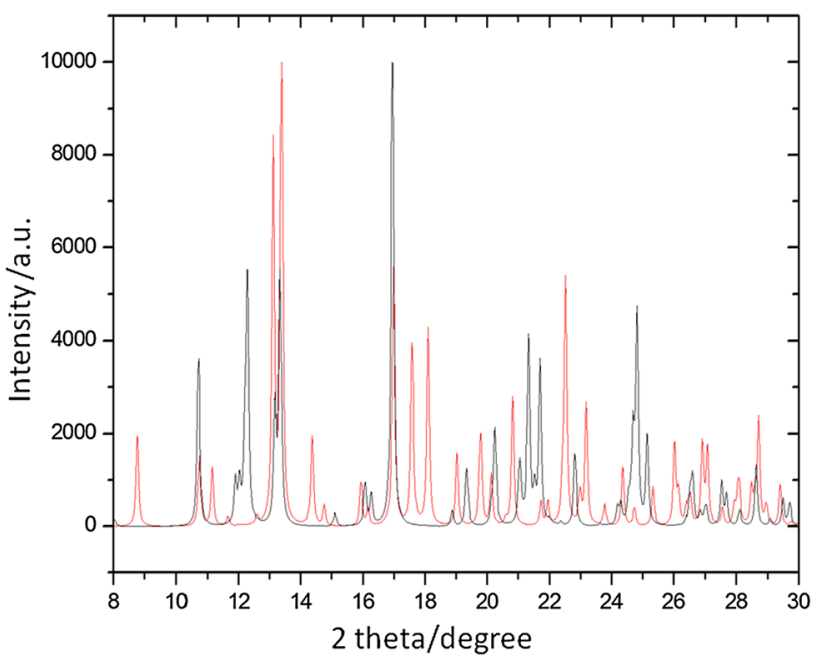

Fig. 3 Comparison of XRPD patterns for salt 1 (red line) and salt reported in [15] (black line) calculated using single crystal data from both polymorphs (color figure online) 


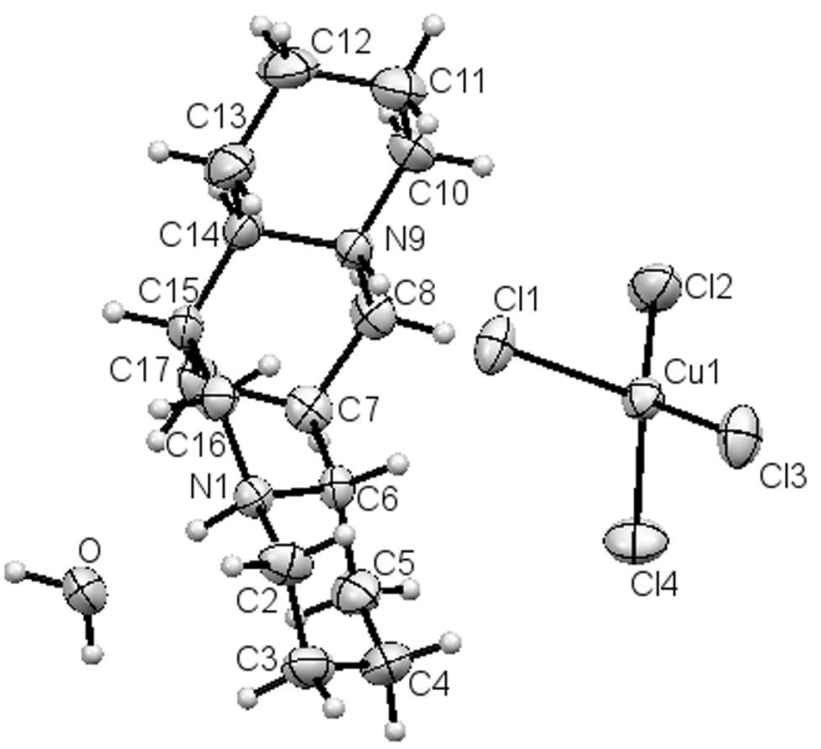

Fig. 4 Molecule of salt $\mathbf{1}$ in the crystal. Ellipsoids correspond to 50\% probability levels

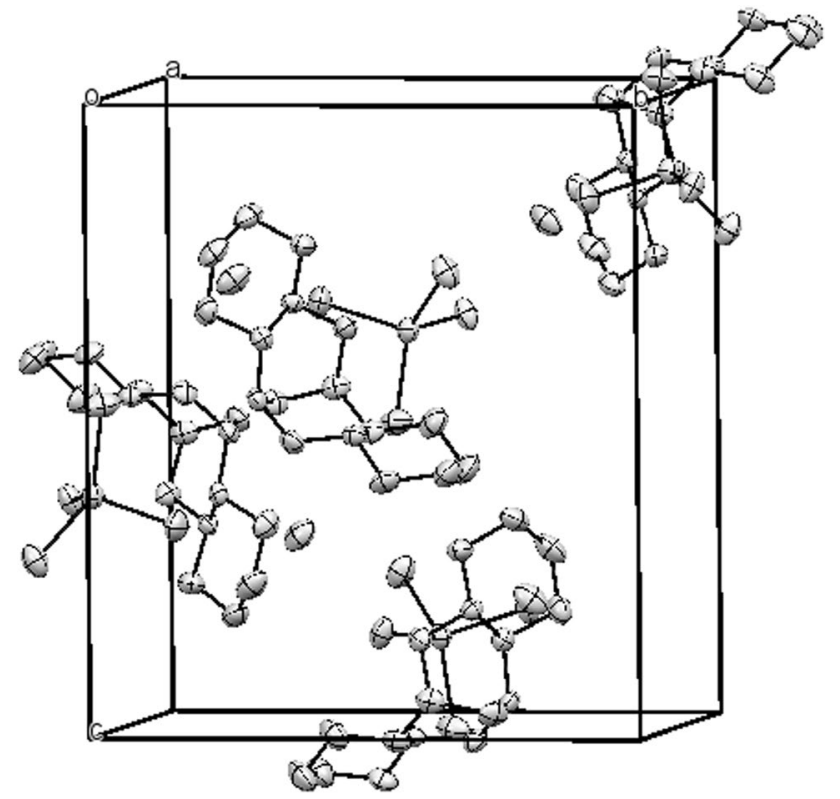

Fig. 5 A view of crystal packing of salt $\mathbf{1}$ in projection along the $a$ axis

both temperatures are almost identical. Distance differences between copper ions were within the 0.05-0.17 $\AA$ range, whereas those for chlorine atoms spanned the 0.076-0.102 range. Likewise, angles occurring in the $\mathrm{CuCl}_{4}^{-2}$ tetrahedral ion are almost identical.

Looking at the arrangement of $\mathrm{CuCl}_{4}^{-2}$ ions in the unit cell along the $z$ axis one can be observe that they are located in planes parallel to (010). When analyzing mutual shift of these planes one notices that they are closer together at $100 \mathrm{~K}(6.680 \AA)$ than at $295 \mathrm{~K}(6.775 \AA)$. Likewise, distances between adjacent anions are shorter at $100 \mathrm{~K}(9.715$ $\AA$ ) than at $295 \mathrm{~K}(9.794 \AA)$.

Considering how vastly different parameters of the unit cell of the obtained salt are, compared to the one obtained earlier by Korean researchers [14], we decided to obtain the salt by proceeding in manner identical to the one reported by them. Pure base (sparteine) was obtained from its sulfate by neutralization. The achieved sparteine exhibited properties agreeing with literature data [14]. Crystallographic studies were performed on the obtained crystals of the salt and it turned out that crystal parameters were identical with those of crystals acquired earlier by us. Despite repeated efforts, we did not manage to obtain crystals of the salt with cell parameters reported in [14].

\section{TGA and DSC studies of the salt}

TGA plot (Fig. 6) reveals loss of crystal water started at $80{ }^{\circ} \mathrm{C}$, and completed at ca. $100{ }^{\circ} \mathrm{C}$. Between 100 and $280^{\circ} \mathrm{C}$ two molecules of $\mathrm{HCl}$ were removed (mass loss ca. $15.9 \%$ ), and finally between 280 and $500^{\circ} \mathrm{C}$ sparteine was removed from the sample (mass loss ca. 51\%). The remnant is $\mathrm{CuCl}_{2}$ (29.2\% of the initial mass).

As mentioned earlier, when cooled down the compound starts changing its color from orange-brown to intense yellow. The process spans several dozen degrees and is reversible, i.e., the initial color returns upon slow warm-up. The results of low-temperature DSC performed in the $+7^{\circ} \mathrm{C}$ to $-140{ }^{\circ} \mathrm{C}$ range $(282-135 \mathrm{~K}$ ) are shown in Fig. $2 \mathrm{~S}$ (supplementary materials). During the cycle starting with cooling, an endothermic process takes place $\left(0{ }^{\circ} \mathrm{C}\right.$ to ca. $\left.-120^{\circ} \mathrm{C}\right)$ with a maximum recorded at $-35.76{ }^{\circ} \mathrm{C}$ and reflected as a wide broad peak corresponding to the previously described color change of the salt. Further heating of the sample leads to the appearance of exothermic, very broad peak (at $-125{ }^{\circ} \mathrm{C}$ to $-30{ }^{\circ} \mathrm{C}$ ) with a maximum at $-99.71{ }^{\circ} \mathrm{C}$. Later cycles of cooling and heating lead to the disappearance of the effect. Subsequently, the examined sample was kept tightly closed and measurements were repeated after 2 and 4 weeks. A similar DSC plot was obtained. Based on these observations and previous literature reports [14], we can conclude that, transitions from one organizational state to another are possible but require both adequate timing and conditions.

\section{IR spectra and Raman spectra of the salt at room temperature}

All IR and Raman vibrations are listed in supplementary materials. The infrared spectrum of salt $\mathbf{1}$ is mainly 


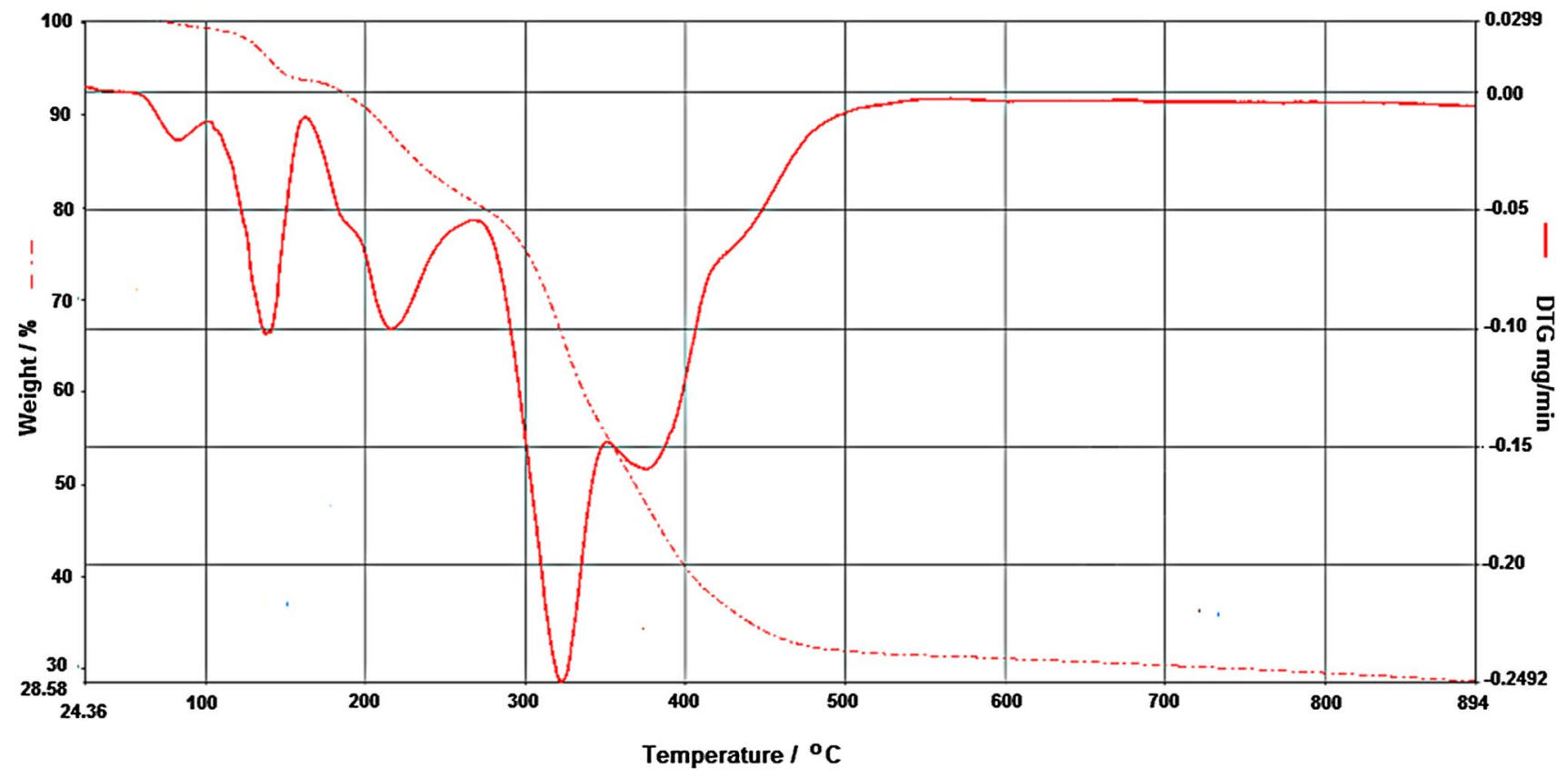

Fig. 6 TGA plot of salt 1

characterized by the vibrational modes of $\mathrm{NH}, \mathrm{OH}$ and $\mathrm{Cu}-\mathrm{Cl}$ units (groups). The Raman spectrum of $\mathbf{1}$ is mainly characterized by the vibrational modes of $\mathrm{Cu}-\mathrm{Cl}$ fragments of $\mathrm{CuCl}_{4}^{-2}$ ions.

Vibration characteristic for two fragments of the salt $\left(\mathrm{CuCl}_{4}^{-2}\right.$ ion and sparteine ligand) can be discerned in both modes. The IR spectrum of salt $\mathbf{1}$ shows very broad band at $3436 \mathrm{~cm}^{-1}$ attributed to $\nu(\mathrm{NH})$ or $\nu(\mathrm{OH})$, while the Raman spectrum shows no bands in this region. The $\mathrm{CuCl}_{4}^{-2}$ roomtemperature IR spectrum shows two strong well-resolved bands near $293 \mathrm{~cm}^{-1}$ and $184 \mathrm{~cm}^{-1}$ attributed to $A_{1}$ stretching frequency and the $T_{2}$ frequency, respectively. In Raman spectrum one could notice a $\nu(\mathrm{Cu}-\mathrm{Cl})$ symmetric stretching frequency at $282 \mathrm{~cm}^{-1}$ and a $T_{2}$ frequency at $181 \mathrm{~cm}^{-1}$. These values are comparable to the literature data for $\mathrm{CuCl}_{4}^{-2}$ salts $[16,17]$.

\section{Conclusion}

Differences in crystal structures occurring between the examined salts with identical molecular formulas permit to conclude the presence of polymorphic variants of the same salt. The study indicates that the reported variant is a stable structure. We did not observe any major structural alterations in this salt at room temperature or at $100 \mathrm{~K}$. Most likely, alterations in crystal structures may occur at temperatures higher than room temperature. Unfortunately, crystals obtained in here were destroyed even with slight heating under a nitrogen sweep. This effect can probably be linked to removal of water molecules from crystals during heating. We were not able to obtain polymorph described in $[14,15]$, and therefore, comparison of spectroscopic data for various polymorphs is not possible except for pointing out the differences in crystallographic structure. DSC-generated data show that changes taking place in crystals of the investigated species depend on the dynamics of heating/cooling manipulations. These changes vanish after several cycles of heating/ cooling but reappear when examined samples are left alone for ca. 1 week or more.

\section{Experimental}

Infrared (IR) spectra were recorded with Nicolet iS50 FT-IR Spectrometer (Thermo Scientific, Warsaw, Poland), using ATR technique. Raman measurements were performed using a Thermo Scientific ${ }^{\mathrm{TM}}$ DXR ${ }^{\mathrm{TM}}$ 2xi Raman imaging microscope equipped with a $780 \mathrm{~nm}$ laser (Thermo Scientific).

Differential scanning calorimetry (DSC) was performed with a DSC Pyris 1 (Perkin Elmer) using aluminum sample pans. The DSC experiments were carried out in a nitrogen atmosphere with a temperature range from 7 to $-140{ }^{\circ} \mathrm{C}$; scanning rate $10{ }^{\circ} \mathrm{C} \mathrm{min}^{-1}$. Thermogravimetric analysis (TGA) was performed with a TGA Pyris 1 (Perkin Elmer) in a nitrogen atmosphere in $25-900{ }^{\circ} \mathrm{C}$ temperature range (scanning rate $10{ }^{\circ} \mathrm{C} \mathrm{min}^{-1}$.)

Single-crystal X-ray experiments were performed at $100 \mathrm{~K}$ or $295 \mathrm{~K}$. The data were collected using a SuperNova kappa diffractometer with Atlas CCD detector (Agilent 
Technologies). Collected data were integrated with CrysAlis Pro software [18]. The structures were solved using direct methods with the SHELXS-2013 software and the solutions were refined using SHELXL-2014/6 program [19]. CCDC1865419 and 1865420 contain supplementary crystallographic data for this paper. These data can be obtained free of charge from The Cambridge Crystallographic Data Centre via: www.ccdc.cam.ac.uk/data_request/cif. X-ray powder diffraction was performed with PAN analytical Empyrean powder diffractometer equipped with PIXcell ${ }^{3 \mathrm{D}}$ detector and a $\mathrm{Cu}-\mathrm{K}_{\alpha}$ radiation source.

Sparteinium tetrachlorocuprate monohydrate (1) was obtained using two methods:

A. from sparteinium sulfate equimolar amounts of ethanolic solutions of sparteine sulfate and hydrated copper(II) chloride were mixed, and yellow precipitate was formed. Concentrated $\mathrm{HCl}$ was added to dissolve the precipitate, upon which the solution turned green. Solvent evaporation led to an appearance of an orange-colored substance. Ethanol and conc. $\mathrm{HCl}$ were then added and the mixture was heated to boiling. A yellow-colored liquid formed from the abovementioned orange precipitate was transferred to another beaker and cooled down. Crystallization yielded small yellow-colored needles which were subsequently used in crystallographic studies.

$B$. from sparteine sparteine was obtained from sparteine sulfate by alkalyzing solution of this salt. Sparteine was then dissolved in saturated methanolic $\mathrm{HCl}$ solution. The latter was then mixed with copper(II) chloride solution and the whole was slightly heated. The obtained solution was left to start crystallization. This led to a product in the form of orange crystals a few of which were chosen for crystallographic studies.

The process of color change and its extent for a given salt was concluded via cooling of the sample (ca. $10 \mathrm{mg}$ ) placed in an NMR tube with internal thermocouple positioned in the cooling mixture (solid $\mathrm{CO}_{2}$ /acetone or liquid nitrogen).

Acknowledgements We wish to thank Dr. Barbara Hachuła for IR and Raman spectra measurement.

Open Access This article is distributed under the terms of the Creative Commons Attribution 4.0 International License (http://creativeco mmons.org/licenses/by/4.0/), which permits unrestricted use, distribution, and reproduction in any medium, provided you give appropriate credit to the original author(s) and the source, provide a link to the Creative Commons license, and indicate if changes were made.

\section{References}

1. Funahashi Y, Nakaya K, Hirota S, Yamauchi O (2000) Chem Lett 29:1172

2. Childers LS, Folting K, Merritt LL Jr, Streib WE (1975) Acta Cryst B31:924

3. Gutiérrez R, Vázquez J, Vázquez RA, Reyes Y, Toscano RA, Martinez M, Álvarez C (2001) J Coord Chem 54:313

4. Johansson A, Vestergren M, Håkansson M, Gustafsson B, Jagner S (2004) New J Chem 28:1000

5. Cady WA, Boschmann E, Choi RS, Heidelman JF, Smith SL (1977) Inorg Chem 16:1958

6. Lee YM, Kim YK, Jeong HC, Kim YI, Choi SN (2002) Bull Korean Chem Soc 23:404

7. Kang SK, Lee Y-M, Kim Y-I, Kim Y, Seff K, Choi S-N (2004) Inorg Chim Acta 357:2602

8. Alcántara-Flores JL, Ramírez-Rosales D, Bernès S, PérezRamírez JG, Durán-Hermández A, Gutiérrez Pérez R, ZamoranoUlloa R, Reyes-Ortega Y (2004) J Mol Struct 693:125

9. Alcántara-Flores JL, Vázquez-Bravo JJ, Gutiérrez Pérez R, Ramírez-Rosales D, Bernès S, Ramírez Bokhimi JG, ZamoranoUlloa R, Reyes-Ortega Y (2003) J Mol Struct 657:137

10. Lopez S, Muravyov I, Pulley SR, Keller SW (1998) Acta Cryst C54:355

11. Jasiewicz B, Boczoń WŁ, Kowalczyk A (2007) J Coord Chem 60:2441

12. Lee Y-M, Kwon M-A, Kang SK, Jeong JH, Choi S-N (2003) Inorg Chem Commun 6:197

13. Jasiewicz B, Sikorska E, Khmelinskii IV, Warżajtis B, Rychlewska U, Boczoń W, Sikorski M (2004) J Mol Struct 707:89

14. Lee YM, Park S-M, Kang SK, Kim Y-I, Choi S-N (2004) Bull Korean Chem Soc 25:823

15. Jasiewicz B, Boczoń W, Muth D, Warżajtis B, Rychlewska U, Andrzejewski B, Toliński T (2006) J Mol Struct 794:311

16. Suffren Y, Rollet F-G, Reber Ch (2011) Comments Inorg Chem $32: 246$

17. Trendafilova N, Nikolov GST, Kellner R, Bauer G (1994) Vib Spectrosc 6:351

18. CrysAlis ${ }^{\text {Pro; }}$; version 1.171.38.41q; Rigaku Oxford Diffraction (2015)

19. Sheldrick GM (2015) Acta Cryst C71:3

Publisher's Note Springer Nature remains neutral with regard to jurisdictional claims in published maps and institutional affiliations. 